\title{
Cancer Cell Metabolism
}

\author{
R.A. CAIrns ${ }^{1,3}$, I. Harris ${ }^{1-3}$, S. MCCRaCKen ${ }^{1}$, AND T.W. MaK ${ }^{1}$ \\ ${ }^{1}$ The Campbell Family Institute for Breast Cancer Research, Toronto, Ontario, Canada M5C2M9 \\ ${ }^{2}$ The Department of Medical Biophysics, University of Toronto, Toronto, Ontario, Canada M5G2C1 \\ Correspondence:tmak@uhnres.utoronto.ca
}

\begin{abstract}
Although the generation of a distinctive metabolic profile is a well-known aspect of cancer, the significance of these adaptations and their potential for exploitation for anticancer therapy has not been fully appreciated until recently. Many oncogenic changes known to affect intracellular signaling pathways play an active role in mediating these metabolic changes, which, in turn, function to support cancer cell growth and replication. In this chapter, we discuss the most current findings in cancer cell metabolism in terms of their impact on tumor cell growth as well as their potential for identifying new targets for therapeutic intervention.
\end{abstract}

With the exception of a few familial predisposition mutations, cancers arise when somatic cells sustain genetic aberrations that disrupt the normal pathways controlling DNA replication and cell growth. Recent advances in genomic sequencing have indicated that tumors collectively exhibit a broad landscape of these genetic changes, but that any given malignancy contains one of a few potent "driver" mutations as well as several less common secondary mutations that combine to promote transformation (Copeland and Jenkins 2009; Hudson et al. 2010). In spite of this genetic complexity, neoplastic cells do exhibit a common phenotype that characterizes the many diseases that we know as cancer (Hanahan and Weinberg 2000, 2010). The most notable feature of this phenotype is unbridled growth, which sustains the invasive potential and lethality of a malignancy. To support this relentless cell division, most cancer cells exhibit shared metabolic adaptations that promote their survival under conditions that kill normal cells; this adaptation process has been termed "metabolic transformation." Consequently, although cellular transformation occurring in different cell types arises from many different pathways, the metabolic requirements of the resulting tumor cells are generally very similar (Fig. 1). Cancer cells must (1) generate energy in the form of ATP, (2) produce precursors for macromolecule biosynthesis to support cell growth, and (3) manage the oxidizing effects of their juggernaut metabolism by reducing the impact of reactive oxygen species (ROS). Because these growth requirements are common to all malignancies, there is currently tremendous research interest in dissecting the mechanisms and impact of metabolic transformation. With such knowledge, it is hoped that therapeutics can be designed to block these adaptations and that these agents may be widely effective at stemming cancer growth and metastasis (Tennant et al. 2010).

In the limited space allowed, this chapter gives a general overview of some well-established and newly discovered mechanisms that cancer cells can employ to satisfy their three growth requirements.

\section{GENERATING ENERGY AND BUILDING BLOCKS: THE WARBURG EFFECT AND BEYOND}

\section{Aerobic Glycolysis}

Metabolic adaptation in tumor cells was one of the first aspects of cancer studied. In the 1920s, Warburg noted that glycolysis, which normally increases under anaerobic conditions, was often enhanced in cancers in the presence of abundant oxygen, a phenomenon known as aerobic glycolysis or the "Warburg effect" (Warburg et al. 1927; Warburg 1956a; Vander Heiden et al. 2009). This switch from oxidative phosphorylation to glycolysis, with its concomitant accumulation of lactate by-products in the tumor microenvironment, represents the best known alteration of tumor cell metabolism (Gillies et al. 2008). It is thought that the resulting increased acidity in the microenvironment promotes tumor cell adaptation and may spur the evolution of the tumor niche (Warburg 1956b; Gatenby and Gillies 2004; Gillies et al. 2008). The prevailing view of the function of the Warburg effect in the past has been that it is a mechanism to produce cellular energy in the form of ATP. Certainly, in the presence of extracellular glucose and robust glucose transport, glycolysis drives ATP production that is more rapid (albeit less efficient) than ATP production via mitochondrial oxidative phosphorylation. Aerobic glycolysis is also beneficial to cancer cells because it generates less ROS and allows the cells to adapt to the intermittently hypoxic conditions prevalent in a poorly vascularized tumor.

The high rates of glucose metabolism associated with the Warburg effect have been effectively exploited to facilitate tumor imaging. Supplying cancers with radioactive glucose derivatives allows them to be examined using

\footnotetext{
${ }^{3}$ These authors contributed equally to this work. 


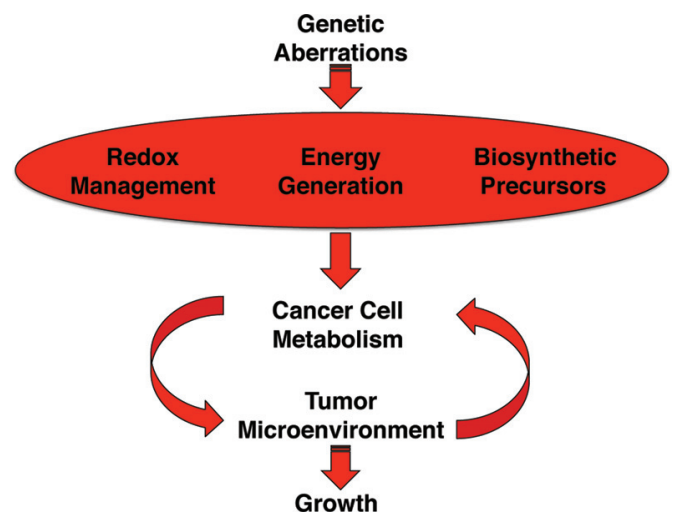

Figure 1. Characteristics of cancer cell metabolism. The altered metabolic profile of transformed cells arises from mutations in genes controlling cellular signaling pathways as well as cellular responses to the surrounding tumor microenvironment. The signaling pathways in which these genetic aberrations occur become oncogenic and drive uncontrolled growth. To meet the metabolic demands of this increased proliferation, cancer cells must produce large amounts of energy and biosynthetic precursors, while managing the high levels of oxidative stress that accompany rapid growth. The ensuing metabolic adaptations also affect the tumor microenvironment, potentially resulting in sporadic hypoxia, acidity, and/or nutrient starvation. Consequently, the tumor microenvironment exerts additional selective pressure on the cancer cells to adapt to the harsh conditions.

${ }^{18}$ fluorodeoxyglucose-positron emission tomography (FDG-PET). Indeed, the tools used to determine the nature of the Warburg effect have demonstrated the clinical importance of glycolysis in cancer cell metabolism (Gambhir et al. 2001; Czernin and Phelps 2002; Gambhir 2002; Jadvar et al. 2009). Consequently, several emerging therapeutic approaches have been designed to inhibit tumor cell glycolysis, ranging from the use of nonmetabolizable glucose analogs to blocking critical steps in the pathway, such as those catalyzed by lactate dehydrogenase (LDH), hexokinase-2 (HK2), or the monocarboxylate transporters (MCT) that export lactate to the external microenvironment (Fantin et al. 2006; Le et al. 2010; Wolf et al. 2011). However, these strategies have not had the hopedfor impact. In addition, subsequent work has shown that the amount of glucose taken up by a cancer cell greatly exceeds its demand for ATP, indicating that the glucose metabolism entails far more than just ATP generation.

\section{Alternative Glucose Metabolism: The Pentose Phosphate Pathway}

Maintaining adequate levels of intracellular nicotinamide adenine dinucleotide phosphate (NADPH) during rapid cell growth is critical for cell survival. Cells can raise their intracellular NADPH by increasing flux through an alternative route of glucose metabolism called the pentose phosphate pathway (PPP). The PPP, which is primarily anabolic, produces ribose sugars for nucleotide biosynthesis and NADPH that serves as reducing potential for the synthesis of macromolecules. When glycolytic precursors or intermediates accumulate, glucose-6- phosphate (G6P) is oxidized by G6P dehydrogenase (G6PDH), triggering commitment to the oxidative arm of the PPP. This arm consists of a series of reactions that catalyze the generation of NADPH by G6PDH and 6phosphoglucuronate dehydrogenase (6PGDH). The lead substrate for the nonoxidative arm of the PPP is ribulose-5-phosphate (R5P), which can be generated either by the oxidative arm or by conversion from fructose-6phosphate. R5P is then processed to ribose sugars that feed into nucleotide biosynthesis. In addition, PPP intermediates generate precursors for amino acids, lipids, and hexosamine sugars via a collection of secondary biosynthetic pathways that support anabolic growth.

\section{Pyruvate Kinase M2}

The availability of biosynthetic precursors is enhanced by regulation of the rate-limiting step of the glycolytic pathway, which is catalyzed in normal cells by pyruvate kinase M1 (PK or PKM1) (Fig. 2). PKM1 drives the conversion of phosphoenolpyruvate (PEP) to pyruvate, with concomitant phosphorylation of ADP to ATP. An alternatively spliced form of PK (PKM2) that has reduced catalytic activity is expressed in cancer cells and can be allosterically activated by fructose-1,6-bisphosphate (FBP) (Christofk et al. 2008a,b; Vander Heiden et al. 2010). This activation can be countered by either phosphotyrosine binding to PMK2 or by phosphorylation of a specific tyrosine residue (Y105) in PMK2 by receptor tyrosine kinases (Christofk et al. 2008b).

Reduced flux through glycolysis causes the accumulation of pathway intermediates, particularly G6P, which is shunted through the PPP. Moreover, PEP accumulation promotes the use of an alternative glycolytic pathway that is uncoupled from ATP synthesis. This alternative pathway, which has not been fully characterized, involves the phosphorylation of phosphoglycerate mutase (PGAM) and maintains the availability of metabolic intermediates when ATP is in excess (Vander Heiden et al. 2010). Moreover, the enzyme phosphoglycerate dehydrogenase (PHGDH), which is frequently amplified in cancer, diverts the glycolytic intermediate, phosphoglycerate, to pathways for glycine and serine biosynthesis (Locasale et al. 2011; Possemato et al. 2011). It is also interesting to speculate that a mechanism observed in yeast, whereby high levels of PEP inhibit triose phosphate isomerase (TPI) and enhance PPP activity, would also benefit cancer cell metabolism (Gruning et al. 2011). These results stress the importance of glycolysis as a source of intermediates to feed the tumor cell's inexorable demand for substrates for macromolecular biosynthesis and suggest that the synthesis of ATP is of secondary importance. Indeed, maintenance of an optimal, but not necessarily maximal, ATP to AMP ratio is critical for preventing the inhibition of upstream glycolytic enzymes such as phosphofructokinase (PFK) (Lehninger et al. 1993). Thus, the Warburg effect is not so much an energy-producing pathway as it is a pipeline for generating reduced NADPH and biosynthetic intermediates essential for cancer cell survival and growth (Fig. 2) (Cairns et al. 2011). 


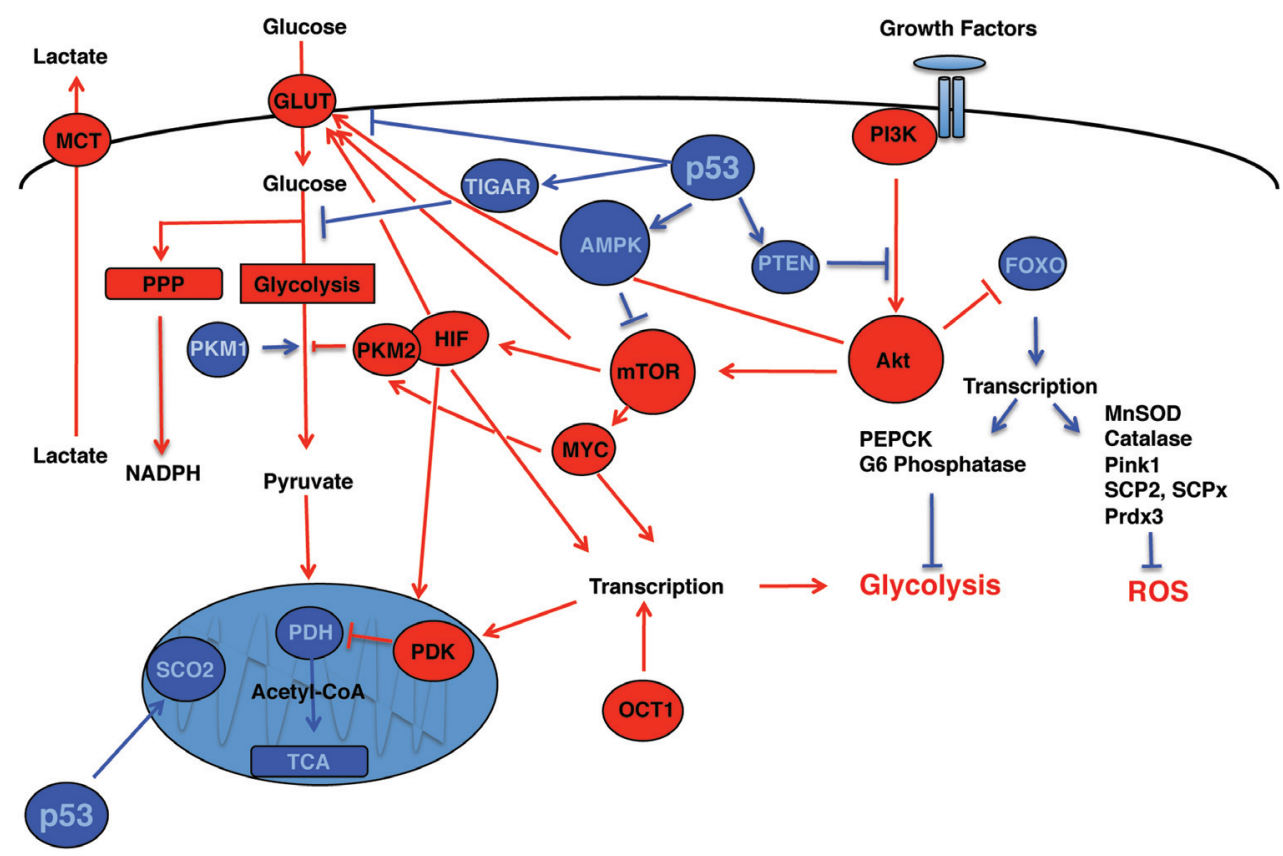

Figure 2. Oncogenic and tumor-suppressive pathways contributing to the Warburg effect. The accelerated rate of aerobic glycolysis characteristic of the Warburg effect is driven by molecular activities that synergistically promote cellular transformation (shown in red). These are countered by other molecular activities that suppress transformation (dark blue). The engagement of growth factor receptors stimulates phosphatidylinositol-3-phosphate kinase (PI3K), which activates Akt1. Activated Akt1 up-regulates glycolysis and activates mTOR while inactivating forkhead box subfamily $\mathrm{O}$ (FOXO). In the absence of FOXOs, transcription of factors that usually inhibit glycolysis and control reactive oxygen species (ROS) is blocked. mTOR activation stimulates translation of growth-related proteins such as Myc and increases hypoxia-inducible factor (HIF) transcriptional activity. HIF1 associates with PKM2 to drive proglycolytic gene expression. PKM2 is an alternatively spliced form of pyruvate kinase (PK or PKM1) and is expressed at high levels in cancer cells. High Myc levels stimulate PKM2 generation, and PKM2 acts to slow glycolysis. Glycolytic intermediates are diverted to the pentose phosphate pathway (PPP), which bolsters nucleotide synthesis and generates NADPH. HIF1 activation also drives the expression of glucose transporters, glycolytic enzymes, and pyruvate dehydrogenase kinase (PDK), which inhibits the entry of pyruvate into the tricarboxylic acid (TCA) cycle via pyruvate dehydrogenase (PDH). PDK expression is also increased by OCT1 transcriptional activity. The production of lactate by lactate dehydrogenase (LDH) is increased owing to increased pyruvate production from glycolysis, and lactate export to the tumor microenvironment is mediated by the monocarboxylate transporters (MCT). Tumor cell metabolic adaptations are countered by tumor suppressors such as p53, phosphatase and tensin homolog deleted from chromosome 10 (PTEN), AMP-dependent kinase (AMPK), TP53-induced glycolysis and apoptosis regulator (TIGAR), FOXOs, and synthesis of cytochrome $c$ oxidase 2 (SCO2). PTEN down-regulates the PI3K pathway, AMPK inhibits mTOR, TIGAR blocks glycolysis, FOXOs control an antioxidative response, thereby increasing ROS scavenging, and the p53 target, SCO2, regulates cytochrome $c$ levels and enhances mitochondrial oxidative phosphorylation. The expression of all these regulators is driven by $\mathrm{p} 53$ and/or FOXO. Loss of these tumor suppressors therefore results in constitutive activation of growth-promoting mechanisms and strongly predisposes cells to transformation.

The alternative splicing event that generates PKM2 is stimulated by the Myc oncoprotein, reinforcing the selective preference for the M2 isoform that occurs under conditions of rapid growth (David et al. 2010; Sun et al. 2011). PKM2 itself further promotes this anabolic program via a positive feedback loop in which PKM2 is hydroxylated by prolyl hydroxylase-3 (PHD3). Hydroxylated PKM2 then interacts with hypoxia-inducible factor 1 (HIF1) to promote the transactivation of HIF-responsive genes (Luo et al. 2011). Because of its high rate of expression as well as its dramatic effect on rates of glycolysis and cell growth, PKM2 has become an attractive candidate for a metabolic biomarker for transformation.

\section{The PI3K Pathway}

The PI3K pathway (Fig. 2) coordinates cellular responses to many extracellular growth/survival signals through a cascade of kinase reactions. Activation of the
PI3K pathway leads to stimulation of glucose uptake and the poising of cellular metabolism toward anabolic growth. These effects synergize to create the strong transforming potential associated with PI3K activation (Plas and Thompson 2005). This transforming activity is counteracted by the tumor suppressor, PTEN, a lipid phosphatase that degrades the second messenger molecule phosphatidylinositol triphosphate (PTDINS-3,4,5-P), which is produced by PI3K. In cancer cells, the PI3K pathway is frequently constitutively activated owing to mutations in the PTEN gene, activating mutations in the catalytic subunit of PI3K itself or hyperactivation/overexpression of receptor tyrosine kinases such as epidermal growth factor receptor 1 (EGFR1) or the insulin-like growth factor 1 receptor (IGF-1R) (Chitnis et al. 2008; Wong et al. 2010).

PI3K activation leads to the activation of the prosurvival kinase Akt1, which in turn results in heightened glucose metabolism through glycolysis and the PPP (Fig. 2) (Elstrom et al. 2004; Fan et al. 2010). Akt1 stimulates 
expression of glucose transporters, enhancing glucose uptake, and directly phosphorylates enzymes such as HK2 and PFK, committing glucose to the glycolytic pathway and driving the Warburg effect (Elstrom et al. 2004; Robey and Hay 2009). Persistent Akt1 up-regulation results in the translocation, ubiquitination, and degradation of the FOXO transcription factors, as well as the up-regulation of HIFs, resulting in an altered transcriptional program that further enhances glycolytic activity (Khatri et al. 2010). FOXOs control the expression of genes important for a variety of cellular processes, including apoptosis, cell cycle progression, and the antioxidant response (Lehtinen et al. 2006; Trachootham et al. 2006; Trotman et al. 2006). Activated Akt1 also increases the expression of ectonucleoside triphosphate diphosphohydrolase 5 (ENTPD5) (Fang et al. 2010). ENTPD5 catalyzes the conversion of uridine $5^{\prime}$ diphosphate (UDP) to uridine $5^{\prime}$ monophosphate (UMP), which stimulates the $N$-glycosylation of proteins in the endoplasmic reticulum (ER). ENTPD5 also works in concert with cytidine monophosphate (CMP) kinase-1 and adenylate kinase-1 to create an ATP hydrolysis cycle that prevents the intracellular energy charge from reaching an inhibitory level (Fang et al. 2010). Interestingly, the increased expression of ENTPD5 serves to amplify the Warburg effect by increasing the ratio of AMP to ATP, thereby maintaining PFK activation. PFK in turn drives glycolysis and promotes the glycosylation of receptors whose translation has been specifically up-regulated. At the same time, the resulting increased glucose influx is channeled into other glucose utilization pathways, such as the generation of UDP-glucose and hexosamine sugars that are used for posttranslational modification of growth factor receptors.

The most dramatic effect of Akt1 phosphorylation is the activation of the downstream kinase mTOR (Fig. 2). This kinase participates in two complexes, mTORC1 and mTORC2, whose equilibrium functions as a major mechanism for nutrient sensing and metabolic transformation. The up-regulation of biosynthetic pathways in response to mTORC1 activation has been studied extensively (Duvel et al. 2010; Zoncu et al. 2010; Yecies and Manning 2011). Once activated, mTORC1 drives protein translation through phosphorylation of the ribosomal small protein 6 (S6) kinase and the eukaryotic translation initiation factor 4E binding protein (eIF4E-BP), enhancing cap-dependent translation of a subset of growth-related proteins such as HIF1, cyclin D, and Myc (Guertin and Sabatini 2007). mTORC1 activation also increases the translation of the serum response element-binding protein and peroxisome proliferatoractivated receptor transcription factors (Guertin and Sabatini 2007; Zhang et al. 2009), stimulating lipid biosynthesis. Lastly, mTORC1 phosphorylates the unc-like kinase 1 protein, inhibiting the formation of complexes initiating autophagy (Chan 2009; Hosokawa et al. 2009). Interestingly, the mTORC2 complex, which predominates under nutrient starvation conditions, participates in a feedback loop that phosphorylates Akt1, up-regulating its activity and thereby controlling the entire mTORcentered network (Sarbassov et al. 2005; Facchinetti et al. 2008; Garcia-Martinez and Alessi 2008; Ikenoue et al. 2008). Dysregulation of the equilibrium between mTORC1 and mTORC2 is thought to be a major driver of metabolic transformation (Duvel et al. 2010; Zoncu et al. 2010; Yecies and Manning 2011).

\section{Hypoxia-Induced Transcription Factors}

The HIF transcription factors, whose expression is up-regulated by the PI3K/Akt1/mTOR pathway, represent secondary mechanisms of adaptation that are driven by external signaling (for review, see in Pouyssegur et al. 2006; Wouters and Koritzinsky 2008). HIF1 and HIF2 are the most significant transcriptional effectors of the cellular response to hypoxia, which is the best characterized form of microenvironmental stress experienced by tumor cells. The HIF $1 \alpha$ and HIF $2 \alpha$ subunits bind to the constitutively expressed HIF1 $\beta$ subunit (also called ARNT) to form two separate dimeric complexes. The stability and hence abundance of the HIF $1 \alpha$ and HIF $2 \alpha$ proteins are tightly controlled by a posttranslational modification process that involves proline hydroxylation, ubiquitination by the von Hippel-Lindau protein ( $p$ VHL), and degradation by the $26 \mathrm{~S}$ proteasome. A reduction in oxygen results in stabilized HIF $1 / 2 \alpha$ subunits and initiates a hypoxic transcriptional response that maximizes glycolysis and minimizes oxidative phosphorylation. Because HIF1 is ubiquitously expressed, whereas HIF2 expression is more restricted, and because the impact of HIF1 on cancer metabolism has been more extensively studied (Bertout et al. 2008), the discussion that follows relates to HIF1 only.

Constitutively active Akt1 can activate HIF1 even under normoxic conditions (Inoki et al. 2005; Plas and Thompson 2005; Lu et al. 2008), as can a deficiency of pVHL (Kaelin 2008; Kapitsinou and Haase 2008), succinic dehydrogenase, or fumarate hydratase (Selak et al. 2005; King et al. 2006). In the latter two cases, the accumulation of the relevant substrates interferes with HIF1 modification. HIF1 stabilization is central to the ability of the PI3K pathway to drive the Warburg effect, because HIF1 enhances cellular glycolytic potential by increasing the transcription of glucose transporters, glycolytic enzymes, and PDK1 (Semenza 2010). Up-regulated PDK1 restricts the entry of pyruvate into the mitochondrial TCA cycle by inhibitory phosphorylation of PDH (Papandreou et al. 2006; Kim et al. 2007; Lu et al. 2008). As a consequence, oxidative phosphorylation and the ROS that it generates are reduced, complementing the up-regulation of glycolysis mediated by HIF1. The concomitant inhibition of FOXOs by Akt1 suppresses FOXO-dependent up-regulation of gluconeogenic enzymes such as glucose-6-phosphatase (G6Pase) and phosphoenolpyruvate carboxykinase (PEPCK), as well as that of several ROS-reducing enzymes, including superoxide dismutase (MnSOD), catalase, and PTEN-induced putative kinase (PINK1) (Lehtinen et al. 2006; Trotman et al. 2006; Zhang et al. 2006; Mei et al. 2009). The expressions of many other factors involved in apoptosis and stress responses are also blocked (Fig. 2) (Trachootham et al. 2006). 
Octamer transcription factor 1 (OCT1; also known as POU domain class 2 transcription factor 1, POU2F1) is another transcription factor that reportedly contributes to the balance between oxidative phosphorylation and glycolysis. OCT1 activates transcription of several genes involved in glycolysis and in the down-regulation of mitochondrial oxidative phosphorylation (Shakya et al. 2009). In particular, OCT1 increases transcription of PDK4, an isozyme of PDK. Both PDK1 and PDK4 inhibit the entry of pyruvate into the TCA cycle by inhibiting PDH. OCT1 is often highly expressed in cancers and may reduce oxidative stress in tumor cells. Consequently, overexpression of OCT1 in conjunction with loss of the master tumor suppressor p53 promotes cellular transformation (Jin et al. 1999; Almeida et al. 2005).

\section{Metabolic Counterbalances to the Warburg Effect and the PI3K Pathway: AMPK, p53, and FOXO}

The PI3K pathway responds to external growth factors and hormonal signals by promoting glucose transport, aerobic glycolysis, and anabolic synthesis of macromolecules. However, in the absence of an abundant supply of glucose, this pathway is ineffective and the cell must rely on other sources of ATP generation. The levels of ATP within a cell are closely monitored by the AMPK, which is activated by increased levels of AMP and whose gene expression is driven by $\mathrm{p} 53$. AMPK initiates suppression of the PI3K pathway by inhibiting both tuberous sclerosis 2 (TSC2) (Inoki et al. 2003) and Raptor, a subunit of mTORC1 (Gwinn et al. 2008). Consequently, AMPK blocks both protein translation and fatty acid (FA) synthesis (Jones et al. 2005; Kuhajda 2008; Shackelford and Shaw 2009) and derepresses autophagy (Kim et al. 2011) by inhibition of mTORC1. To generate energy under these conditions, the cell increases FA oxidation to generate acetyl-coenzyme A (CoA) as a substrate for the TCA cycle and oxidative phosphorylation (Buzzai et al. 2005). AMPK has also been reported to phosphorylate and activate p53, which induces the transcription of genes involved in an energy-dependent cell cycle checkpoint (Jones et al. 2005) as well as inducing genes that down-regulate glycolysis. Finally, AMPK physically interacts with p53 on certain gene promoters to mediate histone $\mathrm{H} 2 \mathrm{~B}$ phosphorylation, thereby increasing transcription (Bungard et al. 2010).

In addition to p53's important roles in the DNA damage response, cell cycle control, and apoptosis, this tumor suppressor also dampens the Warburg effect through its effects on glycolysis and the PI3K pathway (Vousden 2009). In normal cells, p53 stimulates transcription of PTEN, which reduces PTDINS-3,4,5-P levels and thereby inactivates the PI3K pathway. Because p53 is also activated in response to stress and promotes the survival of untransformed cells, some of the effects of p53 activation on the regulation of glucose metabolism through glycolysis and the PPP can seem contradictory to the wellcharacterized role of p53 as a tumor suppressor. p53 increases transcription of the glycolytic enzyme HK2 (Mathupala et al. 1997), which then catalyzes the synthesis of G6P that can enter either glycolysis or the PPP. Simultaneously, p53 drives the expression of the enzyme TIGAR, which dephosphorylates 2,6-FBP (Bensaad et al. 2006) and thus increases flux through the PPP at the expense of glycolysis. In an untransformed cell, these activities of p53 stimulate the production of NADPH that can be used to scavenge ROS. In a cancer cell, p53-mediated stimulation of the PPP would be predicted to promote anabolic cell growth. However, a recent report has described the ability of p53 to bind directly to G6PDH, specifically blocking the oxidative arm of the PPP and thus inhibiting NADPH production (Jiang et al. 2011). Consequently, the overall effect of p53 activation on cancer cell metabolism may be to permit the production of ribose-5-phosphate sugars for nucleotide biosynthesis but deprive the cell of NADPH. In addition, p53 reduces glucose uptake by decreasing the expression of Glut1 and Glut4 (Schwartzenberg-Bar-Yoseph et al. 2004). One can hypothesize a network of HK2, TIGAR, G6PDH, and p53 activities that allows a cell to survive but also to resist transformation. In this way, p53 activates a variety of functions to downplay the changes that occur in cancer cell metabolism and suppress adaptations supporting tumorigenesis. Thus, loss of p53 in a cell removes a major barrier to its transformation and subsequent dysregulated growth.

Like p53, FOXOs control the expression of several metabolic genes. These genes include those encoding G6Pase and PEPCK, which antagonize glycolysis; sestrin 3, which inhibits mTORC1 in a TSC2-independent mechanism; and Rictor, which increases mTORC2 activity (Chen et al. 2010). Inactivation of FOXO by Akt phosphorylation blocks these effects as well as apoptotic pathways induced by FOXO activation (Brunet et al. 1999; Kops et al. 1999; Hay 2011).

\section{Metabolic Flexibility}

Although the Warburg effect is tremendously advantageous for the growth of many cancer cells, it is important to realize that some tumors are not strongly glycolytic (Gambhir et al. 2001; Gambhir 2002). It has become clear that, when necessary, cancer cells can use alternative sources of energy such as the breakdown of FAs, amino acids, and lactate to fuel their proliferation (DeBerardinis et al. 2007; Sonveaux et al. 2008; Yang et al. 2009). One very interesting example of this metabolic flexibility is the abnormal expression in cancer cells of carnitine palmitoyltransferase-1C (CPT1C).

CPT1 enzymes that regulate the $\beta$ oxidation of FAs may play an important part in determining a key aspect of metabolic flexibility. Recent data suggest that CPT1C, in particular, facilitates the adaptation of tumor cells to metabolic stress. CPT1C is normally a brainspecific enzyme that bears significant homology with the ubiquitous CPT1A and muscle-specific CPT1B isozymes (Wolfgang et al. 2006; Wolfgang and Lane 2006). Whereas CPT1A and CPT1B both catalyze the condensation of L-carnitine with acyl-CoA in the outer mitochondrial membrane, CPT1C exhibits very low or 
negligible catalytic activity with conventional substrates, and its subcellular localization is controversial (Wolfgang et al. 2006; Sierra et al. 2008). Nonetheless, CPT1C is an important regulator of lipid metabolism, because mice deficient for CPT1C become obese when fed a high-fat diet, exhibit insulin resistance, and are more prone to developing nonalcoholic fatty liver disease (Wolfgang and Lane 2006, 2011; Wolfgang et al. 2006, 2008; Dai et al. 2007; Lane et al. 2008). In addition, conditional transgenic mice overexpressing CPT1C exhibit microencephaly and an altered profile of very-long-chain FAs in the brain (Reamy and Wolfgang 2011).

With respect to cancer, CPT1C is overexpressed in many human lung tumors, and up-regulated CPT1C expression correlates with rapamycin resistance in a mouse model of HER2 ${ }^{+}$mammary cancer (Zaugg et al. 2011). The evidence to date suggests that CPT1C expression is a mechanism that tumor cells can exploit to increase their chances of survival under stress conditions. Knockdown of CPT1C in cancer cells reduces growth and increases sensitivity to hypoxia and nutrient starvation. Under such conditions of metabolic stress, CPT1C is up-regulated via AMPK activation and stimulates FA oxidation to maintain adequate energy levels. Notably, AMPK and p53 colocalize on the CPT1C promoter and mediate histone $\mathrm{H} 2 \mathrm{~B}$ phosphorylation that stimulates the initiation of CPT1C transcription (Bungard et al. 2010). In line with its regulation by AMPK, the growth advantage conferred by CPT $1 \mathrm{C}$ expression can be blocked by metformin treatment (Zaugg et al. 2011). The induction of CPT1C as a metabolic response to hypoxia suggests that it functions not only to stimulate FA oxidation but also possibly to reduce hypoxia-induced ROS, perhaps through microsomal metabolism of very-long-chain or branched FAs. Consistent with the emerging importance of FA metabolism in tumorigenesis (Menendez and Lupu 2007; Hirsch et al. 2010; Nomura et al. 2010), CPT1C may represent an exciting new target for therapeutic intervention.

\section{METABOLIC ALTERATIONS SUPPORTING BALANCED REDOX STATUS}

\section{Reactive Oxygen Species}

Reactive oxygen species are a heterogeneous collection of highly reactive oxygen compounds that contain an unpaired valence shell electron. Because of their high reactivity, their effects are relatively nonspecific and can have beneficial or detrimental effects (Fig. 3). ROS arise as a natural by-product of mitochondrial oxidative phosphorylation, oxygen metabolism, and NADPH/NADPH oxidase functions. ROS-dependent posttranslational modifications of the kinase and phosphatase systems that regulate cell growth are important for proliferation and intracellular signaling (Lee et al. 2002; Giannoni et al. 2005; Cao et al. 2009). Similarly, ROS-driven activation of HIF1-responsive genes is an essential mechanism by which normal cells manage their intracellular redox balance. HIF-mediated stimulation of glycolysis minimizes further mitochondrial production of ROS and activates

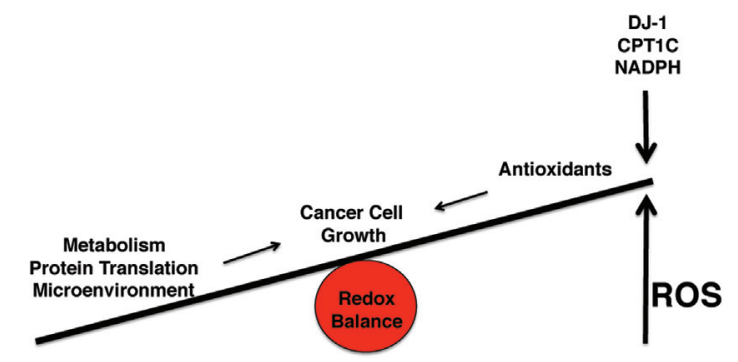

Figure 3. Reactive oxygen species levels in cancer cells. The high metabolic rate of cancer cells drives their intracellular ROS up to an intermediate level, resulting in a shift in redox balance. This oxidizing environment fosters mutations and metabolic adaptations that promote an even higher growth rate and cancer progression. As ROS rise to toxic levels, the cell begins to experience severe oxidative stress, which normally would trigger cell death or senescence. To survive, cancer cells must up-regulate antioxidant mechanisms that can scavenge ROS. In particular, the use of NADPH-mediated mechanisms to reduce ROS, as well as the chaperone activity of DJ1 and metabolic changes effected by carnitine palmitoyltransferase-1C (CPT1C) can help to restore intermediate ROS levels. This maintenance of elevated but nontoxic ROS permits the cell to survive but enables a rapid mutation rate that eventually leads to transformation.

reducing systems that can scavenge these species to prevent collateral damage to cellular structures (Bell et al. 2005; Gao et al. 2007). However, extremely rapid cell growth produces sufficient ROS to inflict serious damage on DNA and to subsequently induce cellular senescence (Ramsey and Sharpless 2006; Takahashi et al. 2006). Alternatively, the apoptosis of cells containing high ROS levels may be triggered through the action of protein kinase $\mathrm{C}-\delta$ or through cytochrome $c$ release from mitochondria (Han et al. 2003; Garrido et al. 2006).

To control excessive ROS levels, cells use scavenging mechanisms involving antioxidants such as reduced glutathione (GSH) and thioredoxin (TRX) (Fruehauf and Meyskens 2007). The oxidation of these reducing molecules consumes excessive ROS, and the reduced forms of these molecules can be regenerated using reducing equivalents derived from NADPH (Fig. 4). In cancer cells, the toll of uncontrolled growth is extremely toxic levels of ROS that must be managed by concomitant up-regulation of ROS scavenging mechanisms. Consequently, although cancer cells do exhibit excessive ROS, these levels would be even higher without the compensatory mechanisms that these cells have evolved (Sundaresan et al. 1995; Bae et al. 1997; Vaughn and Deshmukh 2008; Schafer et al. 2009; Reuter et al. 2010). Moreover, additional inhibition or loss of tumorsuppressing antioxidant systems may tip the redox balance further toward highly toxic and mutagenic levels of ROS. For example, activation of mTORC1 results in an increased rate of protein translation that elevates intracellular ROS (Ozcan et al. 2008). Loss of the tumorsuppressor retinoblastoma protein, which plays a critical role in the antioxidant response, can also lead to toxic ROS levels and apoptosis (Li et al. 2010). Similarly, PTEN inactivation results in elevated Aktl activity, which 


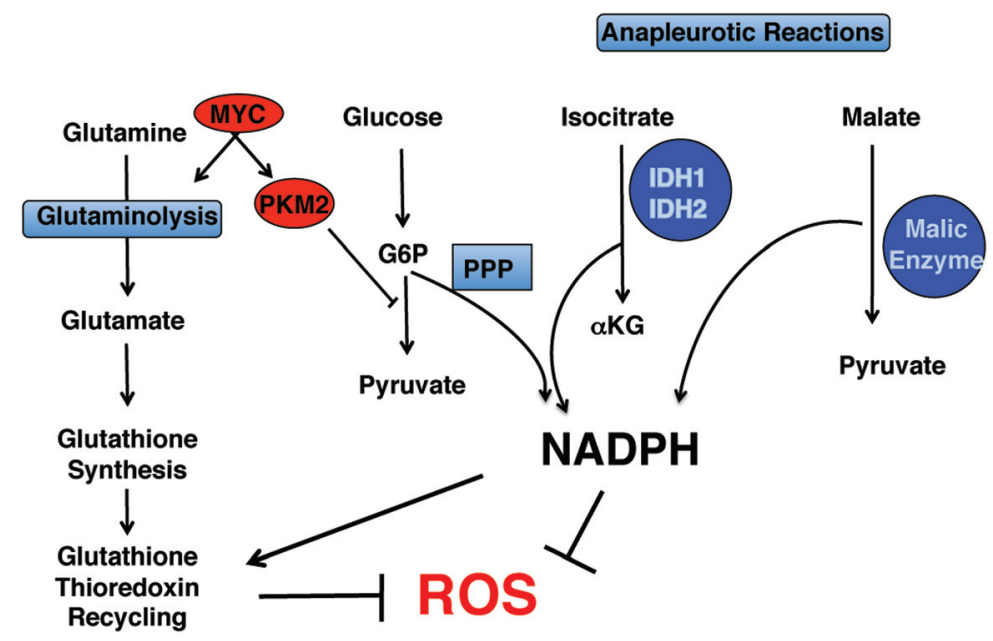

Figure 4. Cellular mechanisms controlling oxidative stress. NADPH is an essential source of reducing power for the recycling of factors such as glutathione and thioredoxin that can scavenge excessive ROS. NADPH is generated both via the PPP and by the cytoplasmic aneuplurotic reactions catalyzed by isocitrate dehydrogenase $1 / 2$ (IDH1/2) and malic enzyme (ME) that also replenish TCA cycle intermediates. Mutations in IDH1/2 may contribute to transformation by reducing NADPH. Glutathione is the end result of a pathway that begins with glutamine uptake and glutaminolysis, and is enhanced by Myc. Myc also increases the expression of PKM2, which slows glycolysis and diverts glucose into the PPP. This diversion is an important counterbalance to the Warburg effect because increased production of NADPH allows cancer cells to neutralize their high ROS levels. Molecules that promote cellular transformation once mutated are shown in red, whereas molecular activities that normally suppress transformation are shown in dark blue.

inhibits FOXOs and further compromises the capacity of the cell to manage ROS (Nogueira et al. 2008).

The role of $\mathrm{p} 53$ in controlling oxidative stress is complex. At moderate levels of oxidative stress, p53 induces the expression of genes that promote cell survival and ROS management (Budanov et al. 2004; Yoon et al. 2004). For example, p53 increases expression of SCO2, which regulates oxidative phosphorylation by controlling cytochrome $c$ oxidase levels, and glutaminase 2, which stimulates glutathione synthesis (Matoba et al. 2006; Suzuki et al. 2010). In addition, p53 activates the transcription of the cyclin-dependent kinase inhibitor p21. p21 associates with nuclear factor (erythroid-derived 2)-like (NRF2, also known as NFE2L2), which is the key regulator of the antioxidant response, to stabilize this transcription factor and thus increase the expression of a broad panel of antioxidant genes (Chen et al. 2009). At low levels of oxidative stress, NRF2 associates with kelch-like ECH-associated protein (KEAP1), which targets NRF2 for ubiquitination and proteolytic degradation. As ROS accumulate, p53-driven expression of p21 increases, preventing NRF2-KEAP interaction and promoting the antioxidant response (Chen et al. 2009).

At extremely high levels of ROS, p53 initiates a failsafe program of apoptosis, maximizing ROS levels through the mitochondrial apoptosis pathway to ensure cell death (Liu et al. 2005, 2008, 2009). In the absence of functional p53, this defense mechanism is lost and ROS inexorably rise, fostering mutagenesis and transformation. Although the extreme oxidative stress that occurs in p53-deficient cells suggests that using oxidative agents to induce lethal ROS levels might be an effective therapy (Trachootham et al. 2006, 2008, 2009), it seems that cancer cells have been selected for the evolution of alternative measures that allow them to adapt to and circumvent the effects of very high ROS, as discussed below.

FOXOs also mediate a major antioxidative response by increasing the expression of MnSOD and catalase, which scavenge superoxide and hydrogen peroxide, respectively, as well as PINK1 and periredoxin3, which manage mitochondrial oxidative stress (Kops et al. 2002; Nemoto and Finkel 2002; Tothova et al. 2007). In addition, FOXOs induce expression the sterol carrier proteins $\mathrm{SCPx} / \mathrm{SCP} 2$, which stimulate peroxisomal metabolism of branchedchain FAs, protect FAs against peroxidation, and function to mitigate the toxicity of oxidized lipids such as cholesterol hydroperoxide (Weinhouse 1976; Dansen et al. 2004; Samuel et al. 2006; Zhang et al. 2006; Weidinger et al. 2008; Kriska et al. 2010).

\section{DJ1}

Recent work has demonstrated that neurons and cancer cells use similar pathways to deal with ROS. DJ1 (also known as Park7) is a molecular chaperone that, like p21, can bind to NRF2 such that it is stabilized and drives the antioxidant response (Clements et al. 2006). In neurodegenerative diseases where DJ1 is deficient, neuronal cells die owing to an inability to reduce oxidative stress (Gasser et al. 1997; Kim et al. 2005a). DJ1 was first identified as an oncogene because of its capacity to synergize with Ras to transform cells (Nagakubo et al. 1997) and was subsequently demonstrated to suppress the effects of PTEN overexpression in a Drosophila genetic screen (Kim et al. 2005b). High levels of DJ1 reduce PTEN stability, resulting in elevated Akt1 activity (Kim et al. 2005a; Aleyasin et al. 2010). Increased DJ1 expression correlates with a poor prognosis for patients 
with lung, ovarian, or esophageal cancers, particularly when p53 is absent (Kim et al. 2005b; Davidson et al. 2008; Yuen et al. 2008). Consistent with these observations, DJ1 deficiency correlates with a reduced risk of developing a wide range of cancers, excluding melanoma (Bajaj et al. 2010).

\section{Glutamine Metabolism in Cancer Cells}

Cancer cell lines require high levels of the amino acid glutamine in culture medium to survive (Eagle 1955; Coles and Johnstone 1962; Reitzer et al. 1979). Although this requirement was originally ascribed to glutamine instability, in fact transformation truly incurs an increased requirement for glutamine (Wise et al. 2008; Gao et al. 2009). The cellular uptake of glucose and glutamine are closely coregulated by the hexosamine biosynthetic pathway, which supports glycosylation of the interleukin-3 receptor $\alpha$ (IL-3R $\alpha)$ subunit as well as growth factordependent glutamine uptake (Wellen et al. 2011). Although this coregulation has been demonstrated only for IL-3R $\alpha$ to date, other cytokine receptors are likely to be controlled in the same way, so that the balance of these two essential nutrients is maintained during rapid growth.

Cytoplasmic glutamine is readily metabolized by glutaminase to generate glutamate that can be used directly for the synthesis of GSH by the enzyme glutathione cysteine ligase, bolstering the antioxidant response (Vaughn and Deshmukh 2008). Alternatively, glutamine can be deaminated to produce $\alpha$-ketoglutarate $(\alpha \mathrm{KG})$ to restore optimal levels of TCA intermediates in a process termed anapleurosis (Fig. 4).

Utilization of glutamine by transformed cells is tightly regulated by Myc, consistent with the increased demand for energy, biosynthetic precursors, and redox management. Myc stimulates glutamine transport (Wise et al. 2008; Gao et al. 2009; Tong et al. 2009) and also represses the expression of miR23a/b, a microRNA that down-regulates expression of glutaminase (Gao et al. 2009). These events occur in addition to the Mycmediated increase in PKM2 alternative splicing and expression described above. The overall effect is the up-regulation of GSH synthesis to scavenge ROS, as well as the stimulation of the PPP to produce NADPH that can be used to regenerate GSH (Fig. 4). Of relevance, it has been demonstrated that cells containing an activating Ras mutation also require high levels of glutamine uptake and processing into GSH to manage oxidative stress (Trachootham et al. 2006; Weinberg et al. 2011).

\section{NADPH}

NADPH is a cofactor that is used to transfer and store reducing potential acquired from cytoplasmic oxidative reactions such as those in the PPP. Approximately 60\% of intracellular NADPH is generated via the PPP, with the remaining $40 \%$ arising from the activities of cytoplasmic isocitrate dehydrogenase (IDH1) and malic enzyme (ME). NADPH is required for anabolic biosynthetic reactions important for cell growth but is also critical for mitigating ROS-related cellular damage. In this capacity, NADPH is used to regenerate both GSH and TRX, which act to reduce ROS toxicity and repair ROSinflicted damage (Nathan and Ding 2010). Consequently, cancer cells maintain high levels of NADPH not only to sustain their rapid growth but also to protect them from excessive ROS.

\section{Isocitrate Dehydrogenases}

Isocitrate dehydrogenases also serve to generate NADPH within a cell. These proteins catalyze the conversion of isocitrate to $\alpha \mathrm{KG}$ with the concomitant production of NADPH (Fig. 4). Cytoplasmic IDH1 and mitochondrial IDH2 are homodimeric enzymes that are highly homologous to each other and use NADP as a cofactor. In contrast, IDH3 functions in the TCA cycle and uses NAD as a cofactor. Several genomic analyses of cancer patients have implicated specific mutations of IDH1 and IDH2 as tumorigenic drivers in a high proportion of low-grade gliomas, astrocytomas, and cytogenetically stable forms of acute myelogenous leukemia (AML) (Parsons et al. 2008; Mardis et al. 2009; Yan et al. 2009; Gross et al. 2010). These studies have demonstrated that the IDH1 R132H mutation is most common in gliomas, whereas the homologous IDH2 R172K or R140Q mutations occurs at similar frequency in AML (Parsons et al. 2008; Mardis et al. 2009; Gross et al. 2010; Ward et al. 2010). The observation that these IDH1/2 mutations are unfailingly heterozygous suggests that they are gainof-function mutations; that is, the mutated genes encode an enzyme that acquires a new function promoting transformation in specific tissues. It is unknown why IDH1/2 mutations are uncommon in other types of cancers (Bleeker et al. 2009; Kang et al. 2009; Yan et al. 2009).

Mutant IDH1/2 enzymes catalyze the normal IDH reaction very inefficiently, leading to reduced intracellular $\alpha \mathrm{KG}$ concentrations. The mutated residues in IDH1 and IDH2 are located at the isocitrate binding site and thus alter the catalytic activity of these proteins. Instead of producing $\alpha \mathrm{KG}$ and NADPH, the mutant IDHs convert $\alpha \mathrm{KG}$ to the rare metabolite 2-hydroxyglutarate (2-HG) while oxidizing NADPH to NADP (Fig. 5) (Dang et al. 2009; Gross et al. 2010; Ward et al. 2010). However, neither cell lines nor tissues expressing mutant IDH proteins show significant changes to other important metabolites such as isocitrate (Dang et al. 2009; Gross et al. 2010). It is currently unclear which effect(s) of IDH mutations are required to achieve cellular transformation: the consumption (rather than the generation) of reducing NADPH equivalents and/or the accumulation of massive intracellular levels of 2-HG (Dang et al. 2009; Gross et al. 2010; Ward et al. 2010). It had been previously hypothesized that a decrease in $\alpha \mathrm{KG}$ would inhibit the $\alpha \mathrm{KG}$-dependent prolyl hydroxylases (PHD) that stabilize HIFs (Zhao et al. 2009). However, it is now believed that the $2-\mathrm{HG}$ produced by mutant IDH1/2 inhibits multiple classes of $\alpha \mathrm{KG}$ dependent dioxygenases ( $\mathrm{Xu}$ et al. 2011), including not only PHDs but also methylcytosine dioxygenase (TET2) enzymes that regulate the methylation state of DNA and 


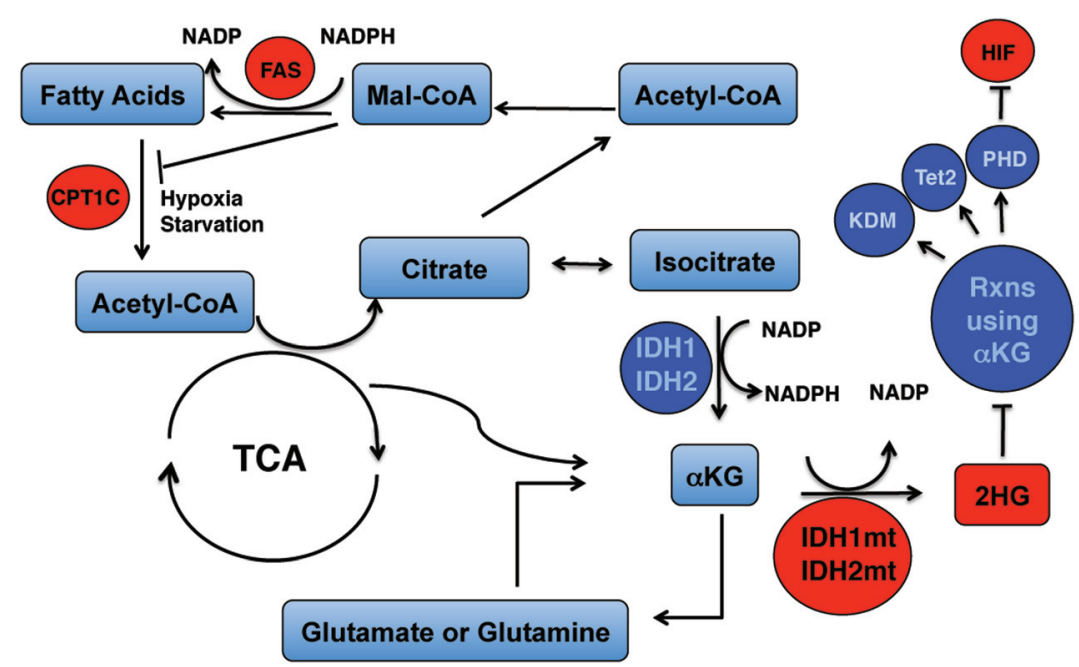

Figure 5. Effects of IDH1 / 2 mutations on cancer cell metabolism. In normal cells (blue), IDH1 / 2 catalyze the conversion of isocitrate to $\alpha$-ketoglutarate $(\alpha \mathrm{KG})$ with concomitant production of NADPH. $\alpha \mathrm{KG}$ generates glutamine and glutamate for the TCA cycle, whereas NADPH provides reducing power for the generation of FAs by FA synthase (FAS). When IDH1/2 are mutated (IDH1/2 $\mathrm{mt}$, shown in red), their altered catalytic activity converts $\alpha \mathrm{KG}$ to 2-HG and consumes NADPH. 2-HG promotes transformation because it inhibits $\alpha \mathrm{KG}$-dependent enzymes such as methylcytosine dioxygenase (TET2), histone lysine demethylases (KDM), and prolyl hydroxylases (PHD), thereby altering DNA methylation and preventing HIF1 degradation. In the presence of metabolic stress such as hypoxia, high ROS levels, or nutrient starvation, this HIF stabilization increases FA oxidation dependent on carnitine palmitoyltransferase 1C (CPT1C), affording cancer cells an alternative energy source. Molecular activities that promote cellular transformation are shown in red, whereas activities that normally suppress transformation are represented in dark blue.

histone lysine demethylases (KDM) that control gene expression epigenetically (Figueroa et al. 2010; Chowdhury et al. 2011). These findings are consistent with the clinical observation that mutations of TET2 and IDH1/2 are mutually exclusive in AML patients (Figueroa et al. 2010). On the basis of these observations, $2-\mathrm{HG}$ has been dubbed an "oncometabolite" whose accumulation is associated with gene silencing and transformation (Dang et al. 2009).

\section{CONCLUSION}

Oncogenic mutations in intracellular signaling pathways produce metabolic adaptations that facilitate tumor growth, a process that is driven in large part by the selective pressure exerted by the surrounding tumor microenvironment. These adaptations must support the energy and biosynthetic requirements of rapidly growing cells while maintaining a balanced redox potential within the cell. Because many of these metabolic changes are common to a broad range of cancer cell types, they are attractive potential targets for anticancer therapy. The ongoing characterization of cancer cell metabolism should yield much useful information that can be translated into therapeutic tools to stem tumor growth and metastasis.

\section{ACKNOWLEDGMENTS}

The authors gratefully acknowledge the support of the Canadian Institutes of Health Research and the Campbell Family Institute for Breast Cancer Research at the
University Health Network. We also thank Dr. Mary Saunders for scientific editing of this review.

\section{REFERENCES}

Aleyasin H, Rousseaux MW, Marcogliese PC, Hewitt SJ, Irrcher I, Joselin AP, Parsanejad M, Kim RH, Rizzu P, Callaghan SM, et al. 2010. DJ-1 protects the nigrostriatal axis from the neurotoxin MPTP by modulation of the AKT pathway. Proc Natl Acad Sci 107: 3186-3191.

Almeida R, Almeida J, Shoshkes M, Mendes N, Mesquita P, Silva E, Van Seuningen I, Reis CA, Santos-Silva F, David L. 2005. OCT-1 is over-expressed in intestinal metaplasia and intestinal gastric carcinomas and binds to, but does not transactivate, CDX2 in gastric cells. J Pathol 207: 396-401.

Bae YS, Kang SW, Seo MS, Baines IC, Tekle E, Chock PB, Rhee SG. 1997. Epidermal growth factor (EGF)-induced generation of hydrogen peroxide. Role in EGF receptor-mediated tyrosine phosphorylation. J Biol Chem 272: 217-221.

Bajaj A, Driver JA, Schernhammer ES. 2010. Parkinson's disease and cancer risk: A systematic review and meta-analysis. Cancer Causes Control 21: 697-707.

Bell EL, Emerling BM, Chandel NS. 2005. Mitochondrial regulation of oxygen sensing. Mitochondrion 5: 322-332.

Bensaad K, Tsuruta A, Selak MA, Vidal MN, Nakano K, Bartrons R, Gottlieb E, Vousden KH. 2006. TIGAR, a p53-inducible regulator of glycolysis and apoptosis. Cell 126: 107120.

Bertout JA, Patel SA, Simon MC. 2008. The impact of O2 availability on human cancer. Nat Rev Cancer 8: 967-975.

Bleeker FE, Lamba S, Leenstra S, Troost D, Hulsebos T, Vandertop WP, Frattini M, Molinari F, Knowles M, Cerrato $\mathrm{A}$, et al. 2009. IDH1 mutations at residue p.R132 (IDH1(R132)) occur frequently in high-grade gliomas but not in other solid tumors. Hum Mutat 30: 7-11.

Brunet A, Bonni A, Zigmond MJ, Lin MZ, Juo P, Hu LS, Anderson MJ, Arden KC, Blenis J, Greenberg ME. 1999. Akt 
promotes cell survival by phosphorylating and inhibiting a Forkhead transcription factor. Cell 96: 857-868.

Budanov AV, Sablina AA, Feinstein E, Koonin EV, Chumakov PM. 2004. Regeneration of peroxiredoxins by p53-regulated sestrins, homologs of bacterial AhpD. Science 304: 596600.

Bungard D, Fuerth BJ, Zeng PY, Faubert B, Maas NL, Viollet B, Carling D, Thompson CB, Jones RG, Berger SL. 2010. Signaling kinase AMPK activates stress-promoted transcription via histone H2B phosphorylation. Science 329: 1201-1205.

Buzzai M, Bauer DE, Jones RG, Deberardinis RJ, Hatzivassiliou G, Elstrom RL, Thompson CB. 2005. The glucose dependence of Akt-transformed cells can be reversed by pharmacologic activation of fatty acid $\beta$-oxidation. Oncogene 24: 4165-4173.

Cairns RA, Harris IS, Mak TW. 2011. Regulation of cancer cell metabolism. Nat Rev Cancer 11: 85-95.

Cao J, Schulte J, Knight A, Leslie NR, Zagozdzon A, Bronson R, Manevich Y, Beeson C, Neumann CA. 2009. Prdx1 inhibits tumorigenesis via regulating PTEN/AKT activity. EMBO J 28: $1505-1517$.

Chan EY. 2009. mTORC1 phosphorylates the ULK1-mAtg13FIP200 autophagy regulatory complex. Sci Signal 2: e51.

Chen W, Sun Z, Wang XJ, Jiang T, Huang Z, Fang D, Zhang DD. 2009. Direct interaction between Nrf2 and p21(Cip1/WAF1) upregulates the Nrf2-mediated antioxidant response. Mol Cell 34: 663-673.

Chen CC, Jeon SM, Bhaskar PT, Nogueira V, Sundararajan D, Tonic I, Park Y, Hay N. 2010. FoxOs inhibit mTORC1 and activate Akt by inducing the expression of Sestrin3 and Rictor. Dev Cell 18: 592-604.

Chitnis MM, Yuen JS, Protheroe AS, Pollak M, Macaulay VM. 2008. The type 1 insulin-like growth factor receptor pathway. Clin Cancer Res 14: 6364-6370.

Chowdhury R, Yeoh KK, Tian YM, Hillringhaus L, Bagg EA, Rose NR, Leung IK, Li XS, Woon EC, Yang M, et al. 2011. The oncometabolite 2-hydroxyglutarate inhibits histone lysine demethylases. EMBO Rep 12: 463-469.

Christofk HR, Vander Heiden MG, Harris MH, Ramanathan A, Gerszten RE, Wei R, Fleming MD, Schreiber SL, Cantley LC. 2008a. The M2 splice isoform of pyruvate kinase is important for cancer metabolism and tumour growth. Nature 452: 230-233.

Christofk HR, Vander Heiden MG, Wu N, Asara JM, Cantley LC. 2008b. Pyruvate kinase M2 is a phosphotyrosine-binding protein. Nature 452: 181-186.

Clements CM, McNally RS, Conti BJ, Mak TW, Ting JP. 2006. DJ-1, a cancer- and Parkinson's disease-associated protein, stabilizes the antioxidant transcriptional master regulator Nrf2. Proc Natl Acad Sci 103: 15091-15096.

Coles NW, Johnstone RM. 1962. Glutamine metabolism in Ehrlich ascites-carcinoma cells. Biochem J 83: 284-291.

Copeland NG, Jenkins NA. 2009. Deciphering the genetic landscape of cancer-From genes to pathways. Trends Genet 25: $455-462$.

Czernin J, Phelps ME. 2002. Positron emission tomography scanning: Current and future applications. Annu Rev Med 53: $89-112$.

Dai Y, Wolfgang MJ, Cha SH, Lane MD. 2007. Localization and effect of ectopic expression of CPT1c in CNS feeding centers. Biochem Biophys Res Commun 359: 469-474.

Dang L, White DW, Gross S, Bennett BD, Bittinger MA, Driggers EM, Fantin VR, Jang HG, Jin S, Keenan MC, et al. 2009. Cancer-associated IDH1 mutations produce 2-hydroxyglutarate. Nature 462: 739-744.

Dansen TB, Kops GJ, Denis S, Jelluma N, Wanders RJ, Bos JL, Burgering BM, Wirtz KW. 2004. Regulation of sterol carrier protein gene expression by the forkhead transcription factor FOXO3a. J Lipid Res 45: 81-88.

David CJ, Chen M, Assanah M, Canoll P, Manley JL. 2010. HnRNP proteins controlled by c-Myc deregulate pyruvate kinase mRNA splicing in cancer. Nature 463: 364-368.
Davidson B, Hadar R, Schlossberg A, Sternlicht T, Slipicevic A, Skrede M, Risberg B, Florenes VA, Kopolovic J, Reich R. 2008. Expression and clinical role of DJ-1, a negative regulator of PTEN, in ovarian carcinoma. Hum Pathol 39: 87-95.

DeBerardinis RJ, Mancuso A, Daikhin E, Nissim I, Yudkoff M, Wehrli S, Thompson CB. 2007. Beyond aerobic glycolysis: Transformed cells can engage in glutamine metabolism that exceeds the requirement for protein and nucleotide synthesis. Proc Natl Acad Sci 104: 19345-19350.

Duvel K, Yecies JL, Menon S, Raman P, Lipovsky AI, Souza AL, Triantafellow E, Ma Q, Gorski R, Cleaver S, et al. 2010. Activation of a metabolic gene regulatory network downstream of mTOR complex 1. Mol Cell 39: 171-183.

Eagle H. 1955. Nutrition needs of mammalian cells in tissue culture. Science 122: 501-514.

Elstrom RL, Bauer DE, Buzzai M, Karnauskas R, Harris MH, Plas DR, Zhuang H, Cinalli RM, Alavi A, Rudin CM, et al. 2004. Akt stimulates aerobic glycolysis in cancer cells. Cancer Res 64: 3892-3899.

Facchinetti V, Ouyang W, Wei H, Soto N, Lazorchak A, Gould C, Lowry C, Newton AC, Mao Y, Miao RQ, et al. 2008. The mammalian target of rapamycin complex 2 controls folding and stability of Akt and protein kinase C. EMBO J 27: $1932-1943$.

Fan Y, Dickman KG, Zong WX. 2010. Akt and c-Myc differentially activate cellular metabolic programs and prime cells to bioenergetic inhibition. J Biol Chem 285: 7324-7333.

Fang M, Shen Z, Huang S, Zhao L, Chen S, Mak TW, Wang X. 2010. The ER UDPase ENTPD5 promotes protein Nglycosylation, the Warburg effect, and proliferation in the PTEN pathway. Cell 143: 711-724.

Fantin VR, St-Pierre J, Leder P. 2006. Attenuation of LDH-A expression uncovers a link between glycolysis, mitochondrial physiology, and tumor maintenance. Cancer Cell 9: 425434.

Figueroa ME, Abdel-Wahab O, Lu C, Ward PS, Patel J, Shih A, Li Y, Bhagwat N, Vasanthakumar A, Fernandez HF, et al. 2010. Leukemic IDH1 and IDH2 mutations result in a hypermethylation phenotype, disrupt TET2 function, and impair hematopoietic differentiation. Cancer Cell 18: 553-567.

Fruehauf JP, Meyskens FL Jr. 2007. Reactive oxygen species: A breath of life or death? Clin Cancer Res 13: 789-794.

Gambhir SS. 2002. Molecular imaging of cancer with positron emission tomography. Nat Rev Cancer 2: 683-693.

Gambhir SS, Czernin J, Schwimmer J, Silverman DH, Coleman RE, Phelps ME. 2001. A tabulated summary of the FDG PET literature. J Nucl Med 42(5 Suppl): 1S-93S.

Gao P, Zhang H, Dinavahi R, Li F, Xiang Y, Raman V, Bhujwalla ZM, Felsher DW, Cheng L, Pevsner J, et al. 2007. HIFdependent antitumorigenic effect of antioxidants in vivo. Cancer Cell 12: 230-238.

Gao P, Tchernyshyov I, Chang TC, Lee YS, Kita K, Ochi T, Zeller KI, De Marzo AM, Van Eyk JE, Mendell JT, et al. 2009. c-Myc suppression of miR-23a/b enhances mitochondrial glutaminase expression and glutamine metabolism. Nature 458: $762-765$.

Garcia-Martinez JM, Alessi DR. 2008. mTOR complex 2 (mTORC2) controls hydrophobic motif phosphorylation and activation of serum- and glucocorticoid-induced protein kinase 1 (SGK1). Biochem J 416: 375-385.

Garrido C, Galluzzi L, Brunet M, Puig PE, Didelot C, Kroemer G. 2006. Mechanisms of cytochrome c release from mitochondria. Cell Death Differ 13: 1423-1433.

Gasser T, Muller-Myhsok B, Wszolek ZK, Durr A, Vaughan JR, Bonifati V, Meco G, Bereznai B, Oehlmann R, Agid Y, et al. 1997. Genetic complexity and Parkinson's disease. Science 277: 388-389; author reply 389 .

Gatenby RA, Gillies RJ. 2004. Why do cancers have high aerobic glycolysis? Nat Rev Cancer 4: 891-899.

Giannoni E, Buricchi F, Raugei G, Ramponi G, Chiarugi P. 2005. Intracellular reactive oxygen species activate Src tyrosine kinase during cell adhesion and anchorage-dependent cell growth. Mol Cell Biol 25: 6391-6403. 
Gillies RJ, Robey I, Gatenby RA. 2008. Causes and consequences of increased glucose metabolism of cancers. J Nucl Med 49(Suppl 2): 24S-42S

Gross S, Cairns RA, Minden MD, Driggers EM, Bittinger MA, Jang HG, Sasaki M, Jin S, Schenkein DP, Su SM, et al. 2010. Cancer-associated metabolite 2-hydroxyglutarate accumulates in acute myelogenous leukemia with isocitrate dehydrogenase 1 and 2 mutations. $J$ Exp Med 207: 339-344.

Gruning NM, Rinnerthaler M, Bluemlein K, Mulleder M, Wamelink MM, Lehrach H, Jakobs C, Breitenbach M, Ralser M. 2011. Pyruvate kinase triggers a metabolic feedback loop that controls redox metabolism in respiring cells. Cell Metab 14: $415-427$.

Guertin DA, Sabatini DM. 2007. Defining the role of mTOR in cancer. Cancer Cell 12: 9-22.

Gwinn DM, Shackelford DB, Egan DF, Mihaylova MM, Mery A, Vasquez DS, Turk BE, Shaw RJ. 2008. AMPK phosphorylation of raptor mediates a metabolic checkpoint. Mol Cell 30: $214-226$.

Han D, Antunes F, Canali R, Rettori D, Cadenas E. 2003. Voltage-dependent anion channels control the release of the superoxide anion from mitochondria to cytosol. $J$ Biol Chem 278: $5557-5563$.

Hanahan D, Weinberg RA. 2000. The hallmarks of cancer. Cell 100: $57-70$

Hanahan D, Weinberg RA. 2010. Hallmarks of cancer: The next generation. Cell 144: 646-674.

Hay N. 2011. Interplay between FOXO, TOR, and Akt. Biochim Biophys Acta. doi:10.1016/j.bbamcr.2011.03.013.

Hirsch HA, Iliopoulos D, Joshi A, Zhang Y, Jaeger SA, Bulyk M, Tsichlis PN, Shirley Liu X, Struhl KA. 2010. Transcriptional signature and common gene networks link cancer with lipid metabolism and diverse human diseases. Cancer Cell 17: 348-361.

Hosokawa N, Hara T, Kaizuka T, Kishi C, Takamura A, Miura Y, Iemura S, Natsume T, Takehana K, Yamada N, et al. 2009. Nutrient-dependent mTORC1 association with the ULK1-Atg13-FIP200 complex required for autophagy. Mol Biol Cell 20: 1981-1991.

Hudson TJ, Anderson W, Artez A, Barker AD, Bell C, Bernabe RR, Bhan MK, Calvo F, Eerola I, Gerhard DS, et al. 2010. International network of cancer genome projects. Nature 464: $993-998$.

Ikenoue T, Inoki K, Yang Q, Zhou X, Guan KL. 2008. Essential function of TORC2 in PKC and Akt turn motif phosphorylation, maturation and signalling. EMBO J 27: 1919-1931.

Inoki K, Zhu T, Guan KL. 2003. TSC2 mediates cellular energy response to control cell growth and survival. Cell 115: $577-590$.

Inoki K, Corradetti MN, Guan KL. 2005. Dysregulation of the TSC-mTOR pathway in human disease. Nat Genet 37: $19-24$.

Jadvar H, Alavi A, Gambhir SS. 2009. 18F-FDG uptake in lung, breast, and colon cancers: Molecular biology correlates and disease characterization. J Nucl Med 50: 1820-1827.

Jiang P, Du W, Wang X, Mancuso A, Gao X, Wu M, Yang X. 2011. p53 Regulates biosynthesis through direct inactivation of glucose-6-phosphate dehydrogenase. Nat Cell Biol 13: $310-316$.

Jin T, Branch DR, Zhang X, Qi S, Youngson B, Goss PE. 1999. Examination of POU homeobox gene expression in human breast cancer cells. Int J Cancer 81: 104-112.

Jones RG, Plas DR, Kubek S, Buzzai M, Mu J, Xu Y, Birnbaum MJ, Thompson CB. 2005. AMP-activated protein kinase induces a p53-dependent metabolic checkpoint. Mol Cell 18: $283-293$.

Kaelin WG Jr. 2008. The von Hippel-Lindau tumour suppressor protein: $\mathrm{O}_{2}$ sensing and cancer. Nat Rev Cancer 8: $865-873$.

Kang MR, Kim MS, Oh JE, Kim YR, Song SY, Seo SI, Lee JY, Yoo NJ, Lee SH. 2009. Mutational analysis of IDH1 codon 132 in glioblastomas and other common cancers. Int J Cancer 125: $353-355$.
Kapitsinou PP, Haase VH. 2008. The VHL tumor suppressor and HIF: Insights from genetic studies in mice. Cell Death Differ 15: $650-659$.

Khatri S, Yepiskoposyan H, Gallo CA, Tandon P, Plas DR. 2010. FOXO3a regulates glycolysis via transcriptional control of tumor suppressor TSC1. J Biol Chem 285: $15960-15965$

Kim RH, Peters M, Jang Y, Shi W, Pintilie M, Fletcher GC, DeLuca C, Liepa J, Zhou L, Snow B, et al. 2005a. DJ-1, a novel regulator of the tumor suppressor PTEN. Cancer Cell 7: $263-273$.

Kim RH, Smith PD, Aleyasin H, Hayley S, Mount MP, Pownall S, Wakeham A, You-Ten AJ, Kalia SK, Horne P, et al. 2005b. Hypersensitivity of DJ-1-deficient mice to 1-methyl4-phenyl-1,2,3,6-tetrahydropyrindine (MPTP) and oxidative stress. Proc Natl Acad Sci 102: 5215-5220.

Kim JW, Gao P, Liu YC, Semenza GL, Dang CV. 2007. Hypoxia-inducible factor 1 and dysregulated c-Myc cooperatively induce vascular endothelial growth factor and metabolic switches hexokinase 2 and pyruvate dehydrogenase kinase 1. Mol Cell Biol 27: 7381-7393.

Kim J, Kundu M, Viollet B, Guan KL. 2011. AMPK and mTOR regulate autophagy through direct phosphorylation of Ulk1. Nat Cell Biol 13: 132-141.

King A, Selak MA, Gottlieb E. 2006. Succinate dehydrogenase and fumarate hydratase: Linking mitochondrial dysfunction and cancer. Oncogene 25: 4675-4682.

Kops GJ, de Ruiter ND, De Vries-Smits AM, Powell DR, Bos JL, Burgering BM. 1999. Direct control of the Forkhead transcription factor AFX by protein kinase B. Nature 398: 630-634.

Kops GJ, Dansen TB, Polderman PE, Saarloos I, Wirtz KW, Coffer PJ, Huang TT, Bos JL, Medema RH, Burgering BM. 2002. Forkhead transcription factor FOXO3a protects quiescent cells from oxidative stress. Nature 419: 316-321.

Kriska T, Pilat A, Schmitt JC, Girotti AW. 2010. Sterol carrier protein-2 (SCP-2) involvement in cholesterol hydroperoxide cytotoxicity as revealed by SCP-2 inhibitor effects. J Lipid Res 51: 3174-3184.

Kuhajda FP. 2008. AMP-activated protein kinase and human cancer: Cancer metabolism revisited. Int J Obes (Lond) 32(Suppl 4): S36-S41.

Lane MD, Wolfgang M, Cha SH, Dai Y. 2008. Regulation of food intake and energy expenditure by hypothalamic malonyl-CoA. Int J Obes (Lond) 32(Suppl 4): S49-S54.

Le A, Cooper CR, Gouw AM, Dinavahi R, Maitra A, Deck LM, Royer RE, Vander Jagt DL, Semenza GL, Dang CV. 2010. Inhibition of lactate dehydrogenase A induces oxidative stress and inhibits tumor progression. Proc Natl Acad Sci 107: 2037-2042.

Lee SR, Yang KS, Kwon J, Lee C, Jeong W, Rhee SG. 2002. Reversible inactivation of the tumor suppressor PTEN by $\mathrm{H}_{2} \mathrm{O}_{2}$. J Biol Chem 277: 20336-20342.

Lehninger AL, Nelson DL, Cox MM. 1993. Principles of Biochemistry. Worth, New York.

Lehtinen MK, Yuan Z, Boag PR, Yang Y, Villen J, Becker EB, DiBacco S, de la Iglesia N, Gygi S, Blackwell TK, et al. 2006. A conserved MST-FOXO signaling pathway mediates oxidative-stress responses and extends life span. Cell 125: 987-1001.

Li L, Qi Z, Qian J, Bi F, Lv J, Xu L, Zhang L, Chen H, Jia R. 2010. Induction of apoptosis in hepatocellular carcinoma Smmc-7721 cells by vitamin $\mathrm{K}(2)$ is associated with p53 and independent of the intrinsic apoptotic pathway. Mol Cell Biochem 342: 125-131.

Liu Y, Borchert GL, Donald SP, Surazynski A, Hu CA, Weydert CJ, Oberley LW, Phang JM. 2005. MnSOD inhibits proline oxidase-induced apoptosis in colorectal cancer cells. Carcinogenesis 26: 1335-1342.

Liu Y, Borchert GL, Surazynski A, Phang JM. 2008. Proline oxidase, a p53-induced gene, targets COX-2/PGE2 signaling to induce apoptosis and inhibit tumor growth in colorectal cancers. Oncogene 27: 6729-6737. 
Liu Y, Borchert GL, Donald SP, Diwan BA, Anver M, Phang JM. 2009. Proline oxidase functions as a mitochondrial tumor suppressor in human cancers. Cancer Res 69: 64146422.

Locasale JW, Grassian AR, Melman T, Lyssiotis CA, Mattaini KR, Bass AJ, Heffron G, Metallo CM, Muranen T, Sharfi H, et al. 2011. Phosphoglycerate dehydrogenase diverts glycolytic flux and contributes to oncogenesis. Nat Genet 43: $869-874$.

Lu CW, Lin SC, Chen KF, Lai YY, Tsai SJ. 2008. Induction of pyruvate dehydrogenase kinase-3 by hypoxia-inducible factor-1 promotes metabolic switch and drug resistance. $J$ Biol Chem 283: 28106-28114.

Luo W, Hu H, Chang R, Zhong J, Knabel M, O’Meally R, Cole RN, Pandey A, Semenza GL. 2011. Pyruvate kinase M2 is a PHD3-stimulated coactivator for hypoxia-inducible factor 1. Cell 145: 732-744.

Mardis ER, Ding L, Dooling DJ, Larson DE, McLellan MD, Chen K, Koboldt DC, Fulton RS, Delehaunty KD, McGrath $\mathrm{SD}$, et al. 2009. Recurring mutations found by sequencing an acute myeloid leukemia genome. New Engl J Med 361: $1058-1066$.

Mathupala SP, Heese C, Pedersen PL. 1997. Glucose catabolism in cancer cells. The type II hexokinase promoter contains functionally active response elements for the tumor suppressor p53. J Biol Chem 272: 22776-22780.

Matoba S, Kang JG, Patino WD, Wragg A, Boehm M, Gavrilova O, Hurley PJ, Bunz F, Hwang PM. 2006. p53 Regulates mitochondrial respiration. Science 312: 1650-1653.

Mei Y, Zhang Y, Yamamoto K, Xie W, Mak TW, You H. 2009. FOXO3a-dependent regulation of Pink1 (Park6) mediates survival signaling in response to cytokine deprivation. Proc Natl Acad Sci 106: 5153-5158.

Menendez JA, Lupu R. 2007. Fatty acid synthase and the lipogenic phenotype in cancer pathogenesis. Nat Rev Cancer 7: $763-777$.

Nagakubo D, Taira T, Kitaura H, Ikeda M, Tamai K, IguchiAriga SM, Ariga H. 1997. DJ-1, a novel oncogene which transforms mouse NIH3T3 cells in cooperation with ras. Biochem Biophys Res Commun 231: 509-513.

Nathan C, Ding A. 2010. SnapShot: Reactive oxygen intermediates (ROI). Cell 140: 951.e2-952.e2.

Nemoto S, Finkel T. 2002. Redox regulation of forkhead proteins through a p66shc-dependent signaling pathway. Science 295: $2450-2452$.

Nogueira V, Park Y, Chen CC, Xu PZ, Chen ML, Tonic I, Unterman T, Hay N. 2008. Akt determines replicative senescence and oxidative or oncogenic premature senescence and sensitizes cells to oxidative apoptosis. Cancer Cell 14: 458470 .

Nomura DK, Long JZ, Niessen S, Hoover HS, Ng SW, Cravatt BF. 2010. Monoacylglycerol lipase regulates a fatty acid network that promotes cancer pathogenesis. Cell 140: 49-61.

Ozcan U, Ozcan L, Yilmaz E, Duvel K, Sahin M, Manning BD, Hotamisligil GS. 2008. Loss of the tuberous sclerosis complex tumor suppressors triggers the unfolded protein response to regulate insulin signaling and apoptosis. Mol Cell 29: $541-551$.

Papandreou I, Cairns RA, Fontana L, Lim AL, Denko NC. 2006. HIF-1 mediates adaptation to hypoxia by actively downregulating mitochondrial oxygen consumption. Cell Metab 3: 187-197.

Parsons DW, Jones S, Zhang X, Lin JC, Leary RJ, Angenendt P, Mankoo P, Carter H, Siu IM, Gallia GL, et al. 2008. An integrated genomic analysis of human glioblastoma multiforme. Science 321: 1807-1812.

Plas DR, Thompson CB. 2005. Akt-dependent transformation: There is more to growth than just surviving. Oncogene 24: $7435-7442$.

Possemato R, Marks KM, Shaul YD, Pacold ME, Kim D, Birsoy K, Sethumadhavan S, Woo H-K, Jang HG, Jha AK, et al. 2011. Functional genomics reveal that the serine synthesis pathway is essential in breast cancer. Nature 476: 346-350.
Pouyssegur J, Dayan F, Mazure NM. 2006. Hypoxia signalling in cancer and approaches to enforce tumour regression. Nature 441: 437-443.

Ramsey MR, Sharpless NE. 2006. ROS as a tumour suppressor? Nat Cell Biol 8: 1213-1215.

Reamy AA, Wolfgang MJ. 2011. Carnitine palmitoyltransferase-1c gain-of-function in the brain results in postnatal microencephaly. J Neurochem 118: 388-398.

Reitzer LJ, Wice BM, Kennell D. 1979. Evidence that glutamine, not sugar, is the major energy source for cultured HeLa cells. J Biol Chem 254: 2669-2676.

Reuter S, Gupta SC, Chaturvedi MM, Aggarwal BB. 2010. Oxidative stress, inflammation, and cancer: How are they linked? Free Radic Biol Med 49: 1603-1616.

Robey RB, Hay N. 2009. Is Akt the "Warburg kinase"? Akt-energy metabolism interactions and oncogenesis. Semin Cancer Biol 19: 25-31.

Samuel VT, Choi CS, Phillips TG, Romanelli AJ, Geisler JG, Bhanot S, McKay R, Monia B, Shutter JR, Lindberg RA, et al. 2006. Targeting foxo1 in mice using antisense oligonucleotide improves hepatic and peripheral insulin action. Diabetes 55: 2042-2050.

Sarbassov DD, Guertin DA, Ali SM, Sabatini DM. 2005. Phosphorylation and regulation of Akt/PKB by the rictor-mTOR complex. Science 307: 1098-1101.

Schafer ZT, Grassian AR, Song L, Jiang Z, Gerhart-Hines Z, Irie HY, Gao S, Puigserver P, Brugge JS. 2009. Antioxidant and oncogene rescue of metabolic defects caused by loss of matrix attachment. Nature 461: 109-113.

Schwartzenberg-Bar-Yoseph F, Armoni M, Karnieli E. 2004. The tumor suppressor p53 down-regulates glucose transporters GLUT1 and GLUT4 gene expression. Cancer Res 64: 2627-2633.

Selak MA, Armour SM, MacKenzie ED, Boulahbel H, Watson DG, Mansfield KD, Pan Y, Simon MC, Thompson CB, Gottlieb E. 2005. Succinate links TCA cycle dysfunction to oncogenesis by inhibiting HIF- $\alpha$ prolyl hydroxylase. Cancer Cell 7: $77-85$.

Semenza GL. 2010. HIF-1: Upstream and downstream of cancer metabolism. Curr Opin Genet Dev 20: 51-56.

Shackelford DB, Shaw RJ. 2009. The LKB1-AMPK pathway: Metabolism and growth control in tumour suppression. Nat Rev Cancer 9: 563-575.

Shakya A, Cooksey R, Cox JE, Wang V, McClain DA, Tantin D. 2009. Oct1 loss of function induces a coordinate metabolic shift that opposes tumorigenicity. Nat Cell Biol 11: 320-327.

Sierra AY, Gratacos E, Carrasco P, Clotet J, Urena J, Serra D, Asins G, Hegardt FG, Casals N. 2008. CPT1c is localized in endoplasmic reticulum of neurons and has carnitine palmitoyltransferase activity. J Biol Chem 283: 6878-6885.

Sonveaux P, Vegran F, Schroeder T, Wergin MC, Verrax J, Rabbani ZN, De Saedeleer CJ, Kennedy KM, Diepart C, Jordan BF, et al. 2008. Targeting lactate-fueled respiration selectively kills hypoxic tumor cells in mice. J Clin Invest 118: $3930-3942$.

Sun Q, Chen X, Ma J, Peng H, Wang F, Zha X, Wang Y, Jing Y, Yang H, Chen R, et al. 2011. Mammalian target of rapamycin up-regulation of pyruvate kinase isoenzyme type M2 is critical for aerobic glycolysis and tumor growth. Proc Natl Acad Sci 108: 4129-4134.

Sundaresan M, Yu ZX, Ferrans VJ, Irani K, Finkel T. 1995. Requirement for generation of $\mathrm{H} 2 \mathrm{O} 2$ for platelet-derived growth factor signal transduction. Science 270: 296-299.

Suzuki S, Tanaka T, Poyurovsky MV, Nagano H, Mayama T, Ohkubo S, Lokshin M, Hosokawa H, Nakayama T, Suzuki Y, et al. 2010. Phosphate-activated glutaminase (GLS2), a p53-inducible regulator of glutamine metabolism and reactive oxygen species. Proc Natl Acad Sci 107: 74617466.

Takahashi A, Ohtani N, Yamakoshi K, Iida S, Tahara H, Nakayama K, Nakayama KI, Ide T, Saya H, Hara E. 2006. Mitogenic signalling and the p16INK4a-Rb pathway 
cooperate to enforce irreversible cellular senescence. Nat Cell Biol 8: $1291-1297$.

Tennant DA, Duran RV, Gottlieb E. 2010. Targeting metabolic transformation for cancer therapy. Nat Rev Cancer 10: 267-277.

Tong X, Zhao F, Thompson CB. 2009. The molecular determinants of de novo nucleotide biosynthesis in cancer cells. Curr Opin Genet Dev 19: 32-37.

Tothova Z, Kollipara R, Huntly BJ, Lee BH, Castrillon DH, Cullen DE, McDowell EP, Lazo-Kallanian S, Williams IR, Sears C, et al. 2007. FoxOs are critical mediators of hematopoietic stem cell resistance to physiologic oxidative stress. Cell 128: 325-339.

Trachootham D, Zhou Y, Zhang H, Demizu Y, Chen Z, Pelicano H, Chiao PJ, Achanta G, Arlinghaus RB, Liu J, et al. 2006. Selective killing of oncogenically transformed cells through a ROS-mediated mechanism by $\beta$-phenylethyl isothiocyanate. Cancer Cell 10: 241-252.

Trachootham D, Zhang H, Zhang W, Feng L, Du M, Zhou Y, Chen Z, Pelicano H, Plunkett W, Wierda WG, et al. 2008 . Effective elimination of fludarabine-resistant CLL cells by PEITC through a redox-mediated mechanism. Blood 112: 1912-1922.

Trachootham D, Alexandre J, Huang P. 2009. Targeting cancer cells by ROS-mediated mechanisms: A radical therapeutic approach? Nat Rev Drug Discov 8: 579-591.

Trotman LC, Alimonti A, Scaglioni PP, Koutcher JA, CordonCardo C, Pandolfi PP. 2006. Identification of a tumour suppressor network opposing nuclear Akt function. Nature 441: $523-527$.

Vander Heiden MG, Cantley LC, Thompson CB. 2009. Understanding the Warburg effect: The metabolic requirements of cell proliferation. Science 324: 1029-1033.

Vander Heiden MG, Locasale JW, Swanson KD, Sharfi H, Heffron GJ, Amador-Noguez D, Christofk HR, Wagner G, Rabinowitz JD, Asara JM, et al. 2010. Evidence for an alternative glycolytic pathway in rapidly proliferating cells. Science 329: 1492-1499.

Vaughn AE, Deshmukh M. 2008. Glucose metabolism inhibits apoptosis in neurons and cancer cells by redox inactivation of cytochrome c. Nat Cell Biol 10: 1477-1483.

Vousden KH. 2009. Functions of p53 in metabolism and invasion. Biochem Soc Trans 37(Pt 3): 511-517.

Warburg O. 1956a. On respiratory impairment in cancer cells. Science 124: 269-270.

Warburg O. 1956b. On the origin of cancer cells. Science 123: $309-314$.

Warburg O, Wind F, Negelein E. 1927. The metabolism of tumors in the body. $J$ Gen Physiol 8: 519-530.

Ward PS, Patel J, Wise DR, Abdel-Wahab O, Bennett BD, Coller HA, Cross JR, Fantin VR, Hedvat CV, Perl AE, et al. 2010. The common feature of leukemia-associated IDH1 and IDH2 mutations is a neomorphic enzyme activity converting $\alpha$-ketoglutarate to 2-hydroxyglutarate. Cancer Cell 17: 225-234.

Weidinger C, Krause K, Klagge A, Karger S, Fuhrer D. 2008 Forkhead box-O transcription factor: Critical conductors of cancer's fate. Endocr Relat Cancer 15: 917-929.

Weinberg F, Hamanaka R, Wheaton WW, Weinberg S, Joseph J, Lopez M, Kalyanaraman B, Mutlu GM, Budinger GR, Chandel NS. 2011. Mitochondrial metabolism and ROS generation are essential for Kras-mediated tumorigenicity. Proc Natl Acad Sci 107: 8788-8793.

Weinhouse S. 1976. Regulation of glucokinase in liver. Curr Top Cell Regul 11: 1-50.

Wellen KE, Lu C, Mancuso A, Lemons JM, Ryczko M, Dennis JW, Rabinowitz JD, Coller HA, Thompson CB. 2011. The hexosamine biosynthetic pathway couples growth factorinduced glutamine uptake to glucose metabolism. Genes Dev 24: 2784-2799.

Wise DR, DeBerardinis RJ, Mancuso A, Sayed N, Zhang XY, Pfeiffer HK, Nissim I, Daikhin E, Yudkoff M, McMahon
SB, et al. 2008. Myc regulates a transcriptional program that stimulates mitochondrial glutaminolysis and leads to glutamine addiction. Proc Natl Acad Sci 105: 18782-18787.

Wolf A, Agnihotri S, Micallef J, Mukherjee J, Sabha N, Cairns R, Hawkins C, Guha A. 2011. Hexokinase 2 is a key mediator of aerobic glycolysis and promotes tumor growth in human glioblastoma multiforme. J Exp Med 208: 313-326.

Wolfgang MJ, Lane MD. 2006. The role of hypothalamic malonyl-CoA in energy homeostasis. $J$ Biol Chem 281: 37265-37269.

Wolfgang MJ, Lane MD. 2011. Hypothalamic malonyl-CoA and CPT1c in the treatment of obesity. FEBS J 278: $552-$ 558.

Wolfgang MJ, Kurama T, Dai Y, Suwa A, Asaumi M, Matsumoto S, Cha SH, Shimokawa T, Lane MD. 2006. The brainspecific carnitine palmitoyltransferase-1c regulates energy homeostasis. Proc Natl Acad Sci 103: 7282-7287.

Wolfgang MJ, Cha SH, Millington DS, Cline G, Shulman GI, Suwa A, Asaumi M, Kurama T, Shimokawa T, Lane MD. 2008. Brain-specific carnitine palmitoyl-transferase-1c: Role in CNS fatty acid metabolism, food intake, and body weight. $J$ Neurochem 105: 1550-1559.

Wong KK, Engelman JA, Cantley LC. 2010. Targeting the PI3K signaling pathway in cancer. Curr Opin Genet Dev 20: 8790 .

Wouters BG, Koritzinsky M. 2008. Hypoxia signalling through mTOR and the unfolded protein response in cancer. Nat Rev Cancer 8: 851-864.

Xu W, Yang H, Liu Y, Yang Y, Wang P, Kim SH, Ito S, Yang C, Xiao MT, Liu LX, et al. 2011. Oncometabolite 2-hydroxyglutarate is a competitive inhibitor of $\alpha$-ketoglutarate-dependent dioxygenases. Cancer Cell 19: 17-30.

Yan H, Parsons DW, Jin G, McLendon R, Rasheed BA, Yuan W, Kos I, Batinic-Haberle I, Jones S, Riggins GJ, et al. 2009. IDH1 and IDH2 mutations in gliomas. New Engl $\mathrm{J}$ Med 360: $765-773$

Yang C, Sudderth J, Dang T, Bachoo RM, McDonald JG, DeBerardinis RJ. 2009. Glioblastoma cells require glutamate dehydrogenase to survive impairments of glucose metabolism or Akt signaling. Cancer Res 69: 7986-7993.

Yecies JL, Manning BD. 2011. mTOR links oncogenic signaling to tumor cell metabolism. $J$ Mol Med 89: 221-228.

Yoon KA, Nakamura Y, Arakawa H. 2004. Identification of ALDH4 as a p53-inducible gene and its protective role in cellular stresses. J Hum Genet 49: 134-140.

Yuen HF, Chan YP, Law S, Srivastava G, El-Tanani M, Mak TW, Chan KW. 2008. DJ-1 could predict worse prognosis in esophageal squamous cell carcinoma. Cancer Epidemiol Biomarkers Prev 17: 3593-3602.

Zaugg K, Yao Y, Reilly PT, Kannan K, Kiarash R, Mason J, Huang P, Sawyer SK, Fuerth B, Faubert B, et al. 2011. Carnitine palmitoyltransferase $1 \mathrm{C}$ promotes cell survival and tumor growth under conditions of metabolic stress. Genes Dev 25: 1041-1051.

Zhang W, Patil S, Chauhan B, Guo S, Powell DR, Le J, Klotsas A, Matika R, Xiao X, Franks R, et al. 2006. FoxO1 regulates multiple metabolic pathways in the liver: Effects on gluconeogenic, glycolytic, and lipogenic gene expression. J Biol Chem 281: $10105-10117$.

Zhang HH, Huang J, Duvel K, Boback B, Wu S, Squillace RM, Wu CL, Manning BD. 2009. Insulin stimulates adipogenesis through the Akt-TSC2-mTORC1 pathway. PLoS One 4: e6189.

Zhao S, Lin Y, Xu W, Jiang W, Zha Z, Wang P, Yu W, Li Z, Gong L, Peng Y, et al. 2009. Glioma-derived mutations in IDH1 dominantly inhibit IDH1 catalytic activity and induce HIF-1 $\alpha$. Science 324: $261-265$.

Zoncu R, Efeyan A, Sabatini DM. 2010. mTOR: From growth signal integration to cancer, diabetes and ageing. Nat Rev Mol Cell Biol 12: 21-35. 


\section{$\$_{\mathrm{CSH}}^{\infty}$ Cold Spring Harbor Symposia SYMPOSIA On Quantitative Biology}

\section{Cancer Cell Metabolism}

R.A. Cairns, I. Harris, S. McCracken, et al.

Cold Spring Harb Symp Quant Biol 2011 76: 299-311 originally published online December 12, 2011

Access the most recent version at doi:10.1101/sqb.2011.76.012856

References This article cites 165 articles, 56 of which can be accessed free at: http://symposium.cshlp.org/content/76/299.full.html\#ref-list-1

\section{License}

Email Alerting

Receive free email alerts when new articles cite this article - sign up in

Service the box at the top right corner of the article or click here. 